Scientific Note

\title{
First occurrence of Silvery Hedge Blue Celastrina gigas (Hemming, 1928) (Insecta: Lepidoptera: Polyommatinae) in West Bengal, India
}

\author{
Primera aparición de Celastrina gigas (Hemming, 1928) (Insecta: Lepidoptera:
}

Polyommatinae) en Bengala Occidental, India

Rajib Dey ${ }^{1}$ (i)

${ }^{1}$ Amarabati Road, Madhyamgram, North 24 Parganas, West Bengal 700130, India. 院 rajibdey88@gmail.com

\section{ZooBank: urn:lsid:zoobank.org:pub:975F4E91-2A56-4DD1-A859-731C16530BA6 https: / / doi.org/ 10.35249/ rche.47.2.21.07}

Abstract. Celastrina gigas is recorded for the first time from Jayanti riverbed $\left(26^{\circ} 41^{\prime} 57^{\prime \prime} \mathrm{N}, 89^{\circ} 36^{\prime} 36^{\prime \prime}\right.$ E). The information on the known and the new distribution is provided along with the photograph. This report will be helpful in updating the distribution of C. gigas in eastern Himalayas.

Key words: Butterfly; Buxa Tiger Reserve; new record; north eastern Himalayas.

Resumen. Se registra por primera vez a Celastrina gigas en el lecho del río Jayanti $\left(26^{\circ} 41^{\prime} 57^{\prime \prime} \mathrm{N}\right.$, $89^{\circ} 36^{\prime} 36^{\prime \prime}$ E). Se proporciona información sobre la distribución conocida y nueva junto con la fotografía de la especie. Este reporte será de utilidad para actualizar la distribución de C. gigas en el este del Himalaya.

Palabras clave: Mariposa; noroeste del Himalaya; nuevo registro; Reserva de Tigres de Buxa.

Eastern Himalayas is one of the 18 biodiversity hotspots of the world and one of the three in India. Buxa Tiger Reserve (BTR) is an extension of Sub-Himalayan West Bengal with an area of $760.87 \mathrm{sq}$. km, which includes a core area of $385 \mathrm{sq} . \mathrm{km}$ and a buffer area of $376 \mathrm{sq}$. km. Geographically it lies between the latitudes of $26^{\circ} 30^{\prime} \mathrm{N}$ and $26^{\circ} 55^{\prime} \mathrm{N}$ and the $89^{\circ} 20^{\prime} \mathrm{E}$ and $89^{\circ} 55^{\prime} \mathrm{E}$. This tropical reserve forest lies between the Bhutan international border in the north, Cooch Bihar district in the south, Assam in the east, and the Jaldapara Wildlife division in the west. The overall geography of the area is enveloped with an amalgamation of plains and hills (Sankar and Das 2015). The area (Fig. 1) was well studied in terms of butterflies. However, more taxonomic works on butterflies from Buxa Tiger Reserve have been done in the last decade (Das et al. 2012; Dey 2019; Sinha et al. 2019; Dey \& Biswas 2020). 9 subspecies belonging to 6 species of Celastrina Tutt, 1906 genus are recorded from India till now (Varshney \& Smetacek 2015), out of which only Celastrina argiolus (Linnaeus, 1758) and Celastrina lavendularis (Moore, 1877) were recorded from West Bengal (Sinha et al. 2019).

Author surveyed butterflies at Jayanti area and Buxa Fort of Buxa Tiger Reserve between 23.1.2019 and 27.1.2019. A single mudpuddling individual of Celastrina gigas (Hemming, 1928) (Fig. 2) was sighted and photographed at Jayanti riverbed, Buxa Tiger Reserve $\left(26^{\circ} 41^{\prime} 57^{\prime \prime} \mathrm{N}, 8^{\circ} 36^{\prime} 36^{\prime \prime} \mathrm{E}\right)$, on 24.1.2019 at 01:10 PM (GMT+5.30). It was observed for more

Received 17 March 2021 / Accepted 12 April 2021 / Published online 23 April 2021

Responsible Editor: José Mondaca E. 
than half an hour at the same place. However, the species was not further observed in that location during the remaining part of the survey despite thorough searching. The species was primarily identified using Kehimkar (2016), and later confirmed by Dr. Trek Lin Seow, Singapore at web-based resources forum (http:/ / www.butterflycircle.com). The observation (https: / www.inaturalist.org/observations / 68449850) has also been classified as a "Research grade observation" in iNaturalist following peer reviewed identification and archived at Global Biodiversity Information Facility (GBIF) (Ueda 2021).
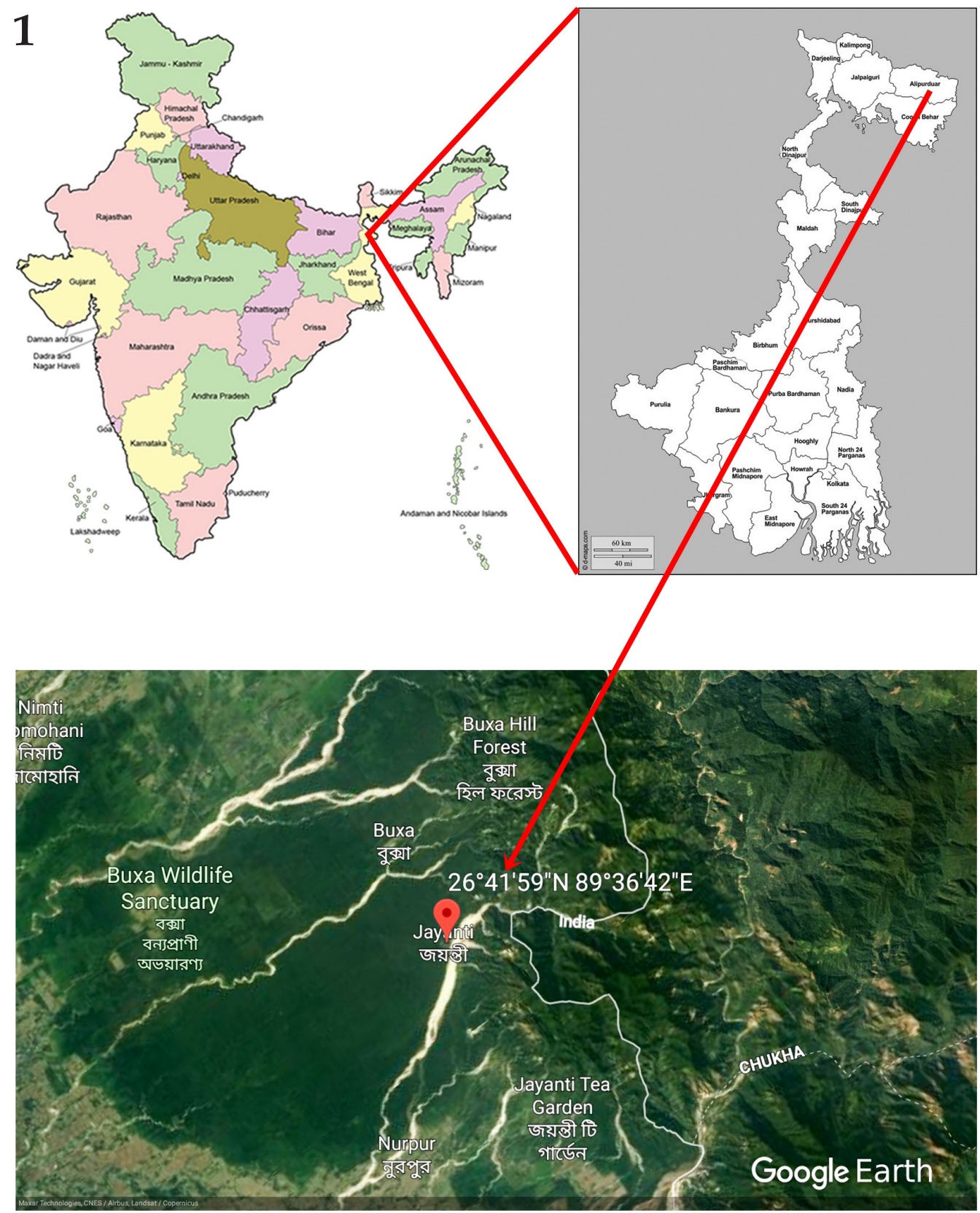

Figure 1. Study area showing new location record of Celastrina gigas in West Bengal, India. / Area de estudio que muestra el nuevo registro de ubicación de Celastrina gigas en Bengala Occidental, India. 


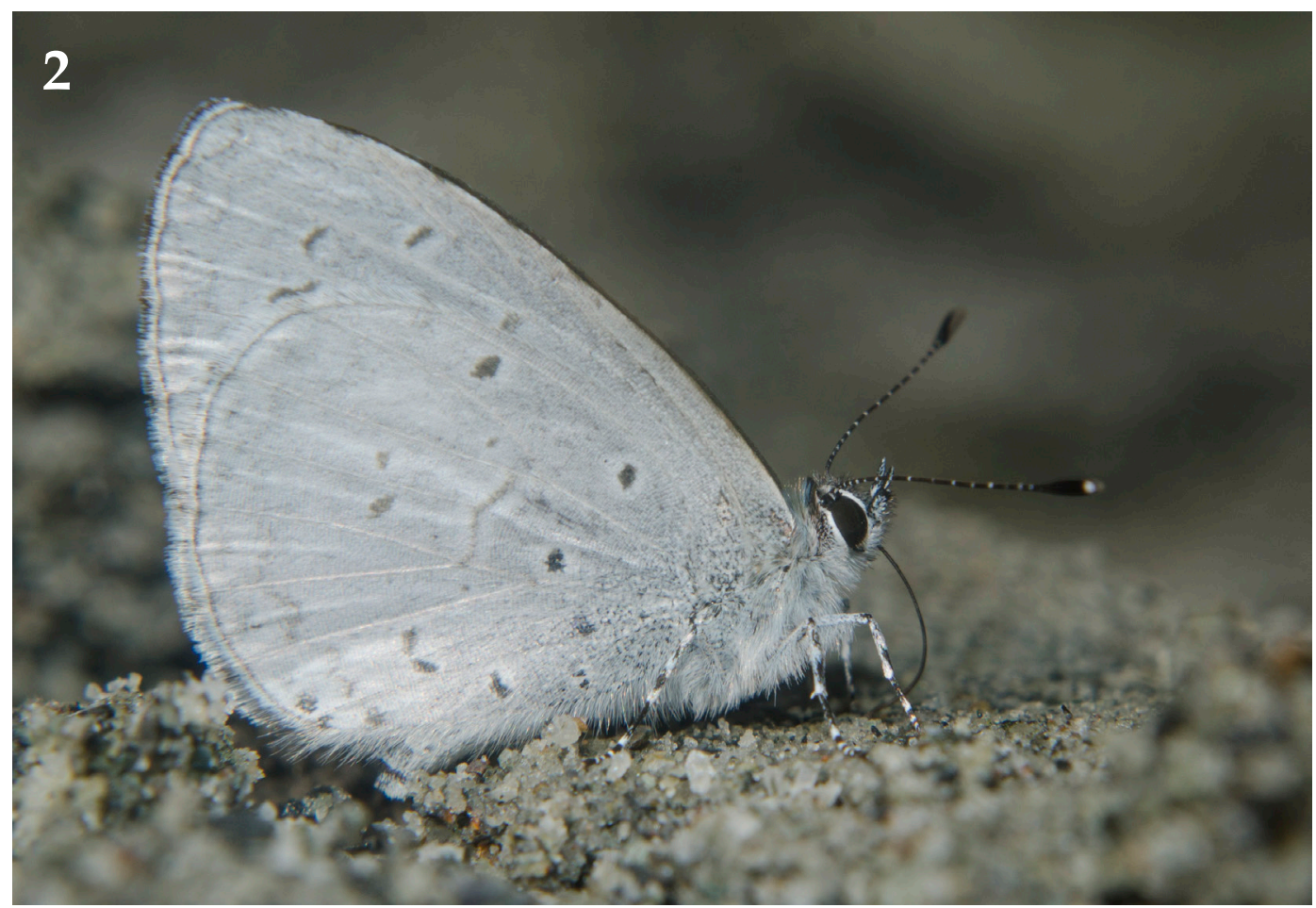

Figure 2. Close-wing puddling behaviour of Celastrina gigas butterfly. / Comportamiento de alas cerradas de la mariposa Celastrina gigas.

The global distribution of C. gigas is in Pakistan, Nepal, and India (Jammu \& Kashmir, Uttarakhand) (Van Gasse 2013; Varshey \& Smetacek 2015). From the eastern Himalayas, C. gigas apparently is not yet recorded. Very recently Sandeep Das recorded this species from Rani Forest $\left(26^{\circ} 33^{\prime} 00^{\prime \prime}\right.$ N, 91 $21^{\circ} 00^{\prime \prime}$ E) in Kamrup district of Assam, about 330 km further east of the present study site. That observation is uploaded on Wikimedia commons website (https: / / en.wikipedia.org). Kehimkar (2016) also stated that the updated distribution of the species in north-west India through the BNHS Field guide "Butterflies of India". Thus, the present report of Celastrina gigas (Hemming, 1928) in West Bengal will help to make an updated checklist.

\section{Acknowledgement}

The author is grateful to Dr. T.L. Seow, Singapore for the identification of species.

\section{Literature Cited}

Das, R.P., Saha, G.K., De, J.K. and Sanyal, A.K. (2012) Diversity and habitat preferences of butterflies in Gorumara National Park, West Bengal, India. Journal of Research in Biology, 2(4): 303-314.

Dey, R. (2019) Confirmation of Eurema simulatrix (Staudinger, 1891) (Lepidoptera: Coliadinae) in West Bengal, India. Bionotes, 21(2): 28.

Dey, R. and Biswas, S. (2020) First record of Prosotas pia Toxopeus (Lepidoptera: Lycaenidae: Polyommatinae) in West Bengal, India. Revista Chilena de Entomología, 46(4): 735-738.

Kehimkar, I. (2016) Butterflies of India. Bombay Natural History Society, Mumbai. xii +528 pp. 
Sarkar, A. and Das, P. (2015) Subsistance use of floral elements in Jainti under Buxa Tiger Reserve in West Bengal, India. Pione, 9(2): 301-310.

Sinha, R.K., Sengupta, S., Roy, A.B., Baidya, S., Roy, S., Das, N., Paul, A. and Pal, A. (2019) Butterflies of Buxa Tiger Reserve. Kolkata, India: CITADEL. 248 pp.

Ueda, K. (2021) iNaturalist Research-grade Observations. iNaturalist.org. Occurrence dataset. https: / / doi.org/10.15468/ ab3s5x accessed via GBIF.org on 2021-02-16. https: / / www.gbif.org/occurrence/3031717439

Van Gasse, P. (2013) Butterflies of India-Annotated Checklist. Available at: https: / / www. ifoundbutterflies.org / images / PaulVanGasse/Butterflies_of\%20_India-Annotated_ checklist-1.pdf Accessed November 28, 2020

Varshney, R.K. and Smetacek, P. (2015) A Synoptic Catalogue of the Butterflies of India. Butterfly Research Centre, Bhimtal and Indinov Publishing, New Delhi, India, ii + 261 pp., 8 pl. 